\title{
Biphasic Calcium Phosphate Ceramics for Bone Regeneration and Tissue Engineering Applications
}

\author{
Sonja Ellen Lobo ${ }^{1,2}$ and Treena Livingston Arinzeh ${ }^{2, *}$ \\ 1 Department of Morphology, Federal University of São Paulo, Rua Botucatu, 740, CEP 04023-900, \\ São Paulo, SP, Brazil; E-Mail: sonjael@terra.com.br \\ 2 Department of Biomedical Engineering, New Jersey Institute of Technology, University Heights; \\ 614 Fenster Hall, Newark, NJ 07102-1982, USA
}

* Author to whom correspondence should be addressed; E-Mail: arinzeh@adm.njit.edu; Tel.: +1-973-596-5269.

Received: 1 December 2009; in revised form: 17 January 2010 / Accepted: 27 January 2010 / Published: 29 January 2010

\begin{abstract}
Biphasic calcium phosphates (BCP) have been sought after as biomaterials for the reconstruction of bone defects in maxillofacial, dental and orthopaedic applications. They have demonstrated proven biocompatibility, osteoconductivity, safety and predictability in in vitro, in vivo and clinical models. More recently, in vitro and in vivo studies have shown that BCP can be osteoinductive. In the field of tissue engineering, they represent promising scaffolds capable of carrying and modulating the behavior of stem cells. This review article will highlight the latest advancements in the use of BCP and the characteristics that create a unique microenvironment that favors bone regeneration.
\end{abstract}

Keywords: calcium phosphate ceramics; bone reconstruction; tissue engineering; stem cell

\section{Introduction}

Calcium phosphate ceramics have been widely applied as bone substitutes, coatings, cements, drug delivery systems and tissue engineering scaffolds due to their resemblance to the mineral portion of the bone tissue, relative ease in processing and good cell attachment [1-4]. Its biocompatibility, safety, predictability, unlimited availability, lower morbidity for the patient and cost effectiveness represent important advantages over autografts and allografts [3,5] and make them a good choice for 
reconstructive surgery, orthopaedics, dentistry, maxillo and craniofacial surgeries, spinal arthrodesis and neurosurgery $[3,5-13]$.

Over the years, several modifications on parameters such as sintering temperature, $\mathrm{pH}$ and purity of the starting products have given rise to calcium phosphates with distinct chemical and physical characteristics such as specific surface areas, surface energy, surface charge, roughness and porosity $[1,3,11,14,15]$. Macropores (diameter $>100 \mu \mathrm{m}$ ) and micropores (diameter $<10 \mu \mathrm{m}$ ) can be created in bioceramics with the use of porogens/pore-formers and heat treatment [14]. As a consequence, it is possible to have a biomaterial that improves the adhesion, proliferation and differentiation of cells, which leads to better osteoconductivity, bioactivity and mechanical properties with less brittleness [11,16-17]. Although studies demonstrate that some bioceramics have osteoinductive properties, the cellular and molecular mechanisms that explain such a process are not completely understood. A few theories have considered the physicochemical and structural characteristics of the bioceramic. It has been described that a high specific surface area, which can be achieved by increasing the number of micropores, is essential for osteoinduction [15,16,18-21]. The presence of concavities, which are present at the walls of macropores, has also been considered a key point, for they resemble the geometric-dependent event of bone formation [22,23]. Furthermore, the dissolution of the surface causes a supersaturation of calcium and phosphate ions, which leads to their reprecipitation and the formation of a biological apatite layer [14,16,18,24-26]. This property allows bone-bonding with the bioceramic and influences its osteoinduction potential.

Among the calcium phosphate ceramics, the biphasic calcium phosphates (BCP), which are composed of different concentrations of the stable phase, hydroxyapatite (HA), and the more soluble phase, usually composed of $\beta$-tricalcium phosphate ( $\beta$-TCP), have presented significant advantages over other calcium phosphate ceramics due to their controlled bioactivity and balance between resorption/solubilization which guarantees the stability of the biomaterial while promoting bone ingrowth [27,28]. Depending upon the concentration of the more stable and soluble phases, it is possible to obtain a ceramic that can be applied to large bone defects, in load bearing areas, and as customized pieces which will maintain their shape over long periods of time [8,28,29].

The nature, timing and progression of bone formation is dependent upon the chemistry and physical properties of the bioceramic $[1,11]$. This review paper describes the physicochemical characteristics of $\mathrm{BCP}$ that create a unique microenvironment for bone formation and their use as a promising tissue engineering scaffold for bone regeneration.

\section{Physicochemical Properties of BCP that Influence Bone Formation}

The type of biological response by the host is critical for bone formation on a bioceramic surface and this response is dependent upon the ceramic's chemical composition and physical structure. A bioceramic can be classified according to the type of interface formed between the bioceramic and the host tissue. A bioceramic can be classified as inert (where there is a minor fibrous reaction by the host on the surface of the biomaterial) and bioactive (where there is a direct biochemical and biological bond at the interface with the adjacent bone tissue, via the formation of an apatite layer at the surface of the biomaterial). This interface influences the rate and type of bone formation and the stability and 
mechanical strength at the interface, which can play a role in the success or failure of the implant [12,30].

Thus, three generations of bioceramics have been described: the first is characterized as inert materials (e.g., alumina and zirconia) in which the bone substitutes cause a mild inflammatory response and result in a minor fibrous encapsulation [31]. The second generation corresponds to bioactive biomaterials which are explained by a sequential transition between the nucleation of an amorphous calcium phosphate layer, formation of octacalcium phosphate and finally, the maturation into a calcium deficient carbonated hydroxyapatite layer [31]. Bioactive glasses, highly porous HA and macroporous BCP ceramics are examples of biomaterials with such a property [14,32]. Finally, the third generation corresponds to bioactive materials with different porosities, better mechanical properties and chemical compositions that allow improved ion exchange and leads to osteogenesis $[12,31,32]$. BCP ceramics can be fabricated that promote the formation of bone with mature bone structure, including a Haversian-like system, and a low level of an inflammatory response [17,26,31,32] (Figure 1).

Figure 1. Histological and radiographical images of a BCP (Osteosynt $\left.{ }^{\circledR}\right)$ in granular form (40-60 mesh or approx. 250 to $420 \mu \mathrm{m}$ ). (a) Histological image after implantation in a rabbit femur (250X, Toluidine blue); (b) Radiographic image after the reconstruction of a tibial defect in a human (surgical procedure performed by Dr C. A. Garrido). BT = bone tissue; $\mathrm{C}=$ ceramics.

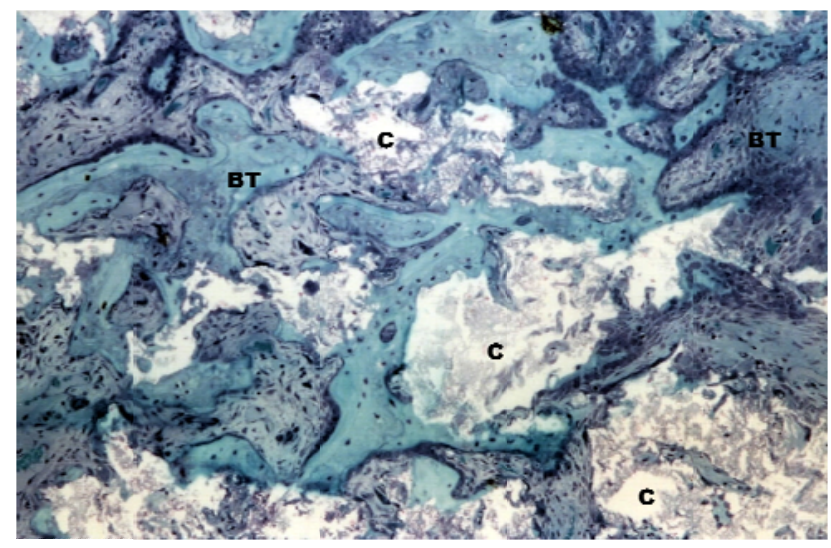

(a)

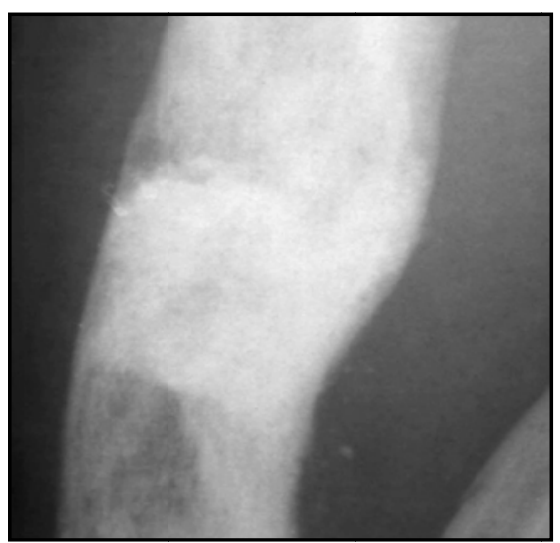

(b) 
Bone formation within a ceramic is a multifactor process that is regulated by several aspects such as chemical composition, resorption and dissolution rates, physical structure (e.g., geometry of the pores, porosity as well as surface topography) and implantation site. The chemical composition of a bioceramic influences the rate of solubilization/resorption as well as its bioactivity. For instance, while HA is slowly resorbed and/or solubilized, calcium sulphate, $\alpha$-TCP and $\beta$-TCP undergoes a much faster process of resorption. In addition, the rate of resorption can be manipulated by ionic substitutions of some salts. The two most described examples are the carbonate and the silicatesubstitute calcium phosphates ( $\mathrm{Si}-\mathrm{CaP}$ ) that can present an increased rate of resorption when compared to the stoichiometric HA $[11,33,34]$. A completely resorbable ceramic has been the goal of several studies; however, a high rate of resorption or solubilization can interfere with bone formation as the biomaterial may degrade faster than the rate of bone formation. This phenomena leads to a change in the bioceramic's physical structure, i.e., loss of the concavity in the macropore and the mechanical stability of the surface, which will interfere with cell attachment [16,35]. Moreover, the release of high concentrations of calcium to the microenvironment results in a change of the $\mathrm{pH}$, promotes a mild inflammatory response and favors fibrous tissue formation [11,36]. Furthermore, higher calcium ion levels have been shown to effect osteoclastic activity, varying from its inhibition to its stimulation or no effects [37,38]. Consequently, a ceramic with a lower resorption rate is stable for enough period of time to allow for the formation of new bone by the host tissue [8]. In addition, the release of controlled levels of calcium ions over time favors the formation of an apatite layer, which is necessary for the bioactivity displayed in HA/ $\beta$-TCP ceramics $[15,25,28]$. This bioactivity can be responsible for the ceramic's osteoconductivity and/or osteoinductivity. In osteoconduction, the biomaterial surface supports the growth of mature osteoblasts and direct apposition of bone onto its surface while in osteoinduction, the biomaterial favors the recruitment of immature or undifferentiated cells and stimulates their differentiation towards the osteoblastic lineage and as a consequence, osteogenesis will be stimulated $[11,39]$.

The advantages and disadvantages of a bioceramic with high and low resorption or dissolution rates have been widely discussed. The resorption process refers to the cell-mediated mechanism while the dissolution refers to the chemical process that results from the reaction with the surrounding body fluids $[1,11,19]$. It is important to highlight that nanoparticles $(0.1-100 \mathrm{~nm})$ can undergo a process of phagocytosis/endocytosis and not dissolution or resorption [11,40]. Nanoparticles of distinct chemical compositions can enter the cells through gap junctions or hemichannels and can result in DNA damage, alteration of the cell shape and size and cell death [40-43]. Hydroxyapatite nanoparticles have been studied as a potential therapy for the suppression and apoptosis of osteosarcoma cells, where larger-sized particles appear to be more effective than the smaller ones [43]. The particle size has also been related to the modulation of the inflammatory process: the smaller the particle, the higher the inflammatory process [44] and can also interfere in the in vitro differentiation of stem cells [45]. However, this characteristic should not be confused with nanostructured ceramics in which the surface texture improves the attachment and differentiation of osteoprogenitor cells and favors protein adsorption due to its increased surface energy [12,46] (Figure 2). 
Figure 2. SEM image of human mesenchymal stem cells seeded onto a nanostructured BCP (Osteosynt $\left.{ }^{\circledR}\right)$.

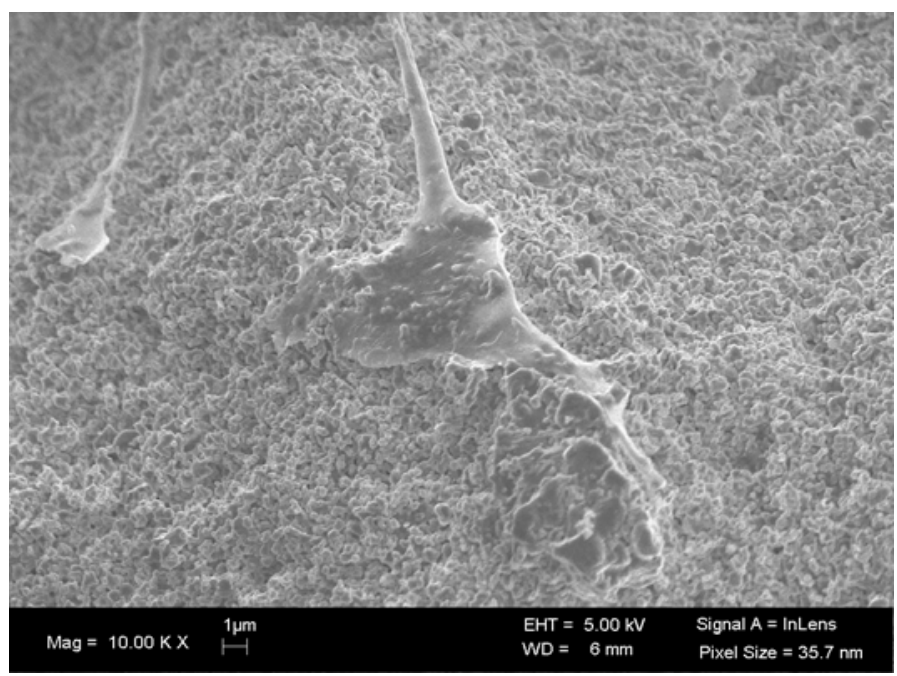

The physical structure of bioceramics is represented by the surface topography and by the pore structure. Studies have shown that a concave surface favors cell adhesion and proliferation in comparison to a convex surface and is responsible for the beginning of the bone formation process $[22,23,47]$. The presence of a macroporous structure favors cell ingrowth and blood vessel invasion while the microporosity allows the penetration of body fluids into the implant and increases its bioactivity. Consequently, microporosity can also be a strategy to manipulate the resorption and dissolution rate: the greater the microporosity, the greater the degradation rate $[1,11,14,48,49]$. Microporosity has been described as one of the factors that influence the intrinsic osteoinductivity of some calcium phosphate ceramics [15,16,18-21]. Micropores allow for the entrapment and concentration of proteins which, in when contact with undifferentiated cells, will induce their differentiation [47,50].

Therefore, an understanding of the physiochemical characteristics is extremely important when choosing a bioceramic, specifically $\mathrm{BCP}$, as it determines the nature, timing and progress of the tissue formation. In addition, the type and rate of new bone formation depends on the age, systemic condition, metabolism and lifestyle of the patient, the anatomic area that has to be reconstructed, the size of the bone defect, the existence or absence of walls that contain the bioceramic and the surgical technique $[8,10,11,13,46]$. Different areas of the human skeleton present distinct functional loads, bone density (ratio between the cortical and the medullar zones) and degree of vascularization [46]. This can, in turn, influence the rate of degradation of the ceramic and the overall remodeling process [32].

\section{BCP Ceramics in Bone Tissue Engineering}

A biomaterial that is capable of reconstructing small bone defects may not be suitable to regenerate large bone defects [5], where the current approach includes different types of bone grafts [51]. BCP ceramics have been considered to be a promising scaffold for use with tissue engineering strategies for large bone defect reconstruction. With the aim of improving their osteogenic potential and mechanical 
properties, such scaffolds have been mixed with autografts, fibrin, platelet concentrate, several growth factors, cytokines and more recently with expanded cells isolated from several tissues $[6,9,17,46,52-55]$.

Autologous and allogeneics stem cells have been isolated from different tissues; however mesenchymal stem cells (MSC) from the bone marrow are the most studied (Figure 3). Whole bone marrow in combination with a scaffold was one of the first strategies described to improve the osteogenic potential of synthetic scaffolds [3]. In subsequent studies, MSC isolated from the bone marrow, which is the osteogenic cell population within the bone marrow, were used in combination with scaffolds to treat bone defects [56]. MSC were expanded in culture and seeded at high densities onto large, porous blocks of BCP. Critically-sized segmental defects in various animal species have been treated with this approach and have formed functional bone tissue in vivo. These constructs have been shown to simulate the events of bone formation observed with autologous bone grafts in long bone defects [51].

Figure 3. SEM images of the adhesion and proliferation of human mesenchymal stem cells seeded onto a nanostructured BCP ceramic (Osteosynt ${ }^{\circledR}$ ), in the granular form corresponding to 40-60 mesh (approx. 250 to $420 \mu \mathrm{m}$ ). (a) day 1; (b) day 7; (c) day 14.

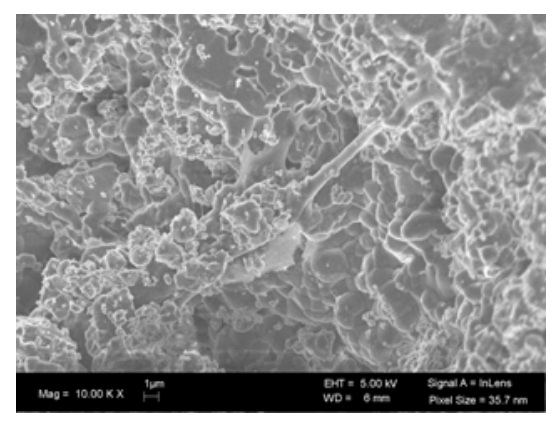

(a)

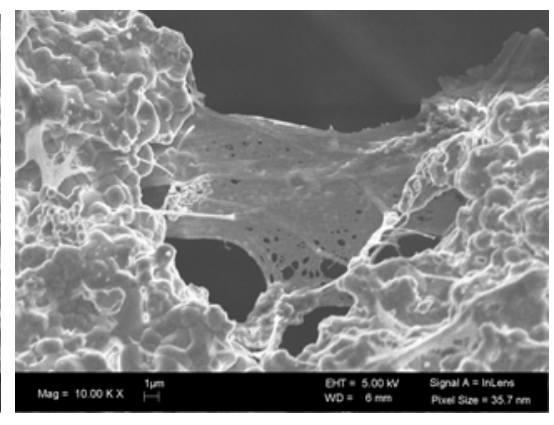

(b)

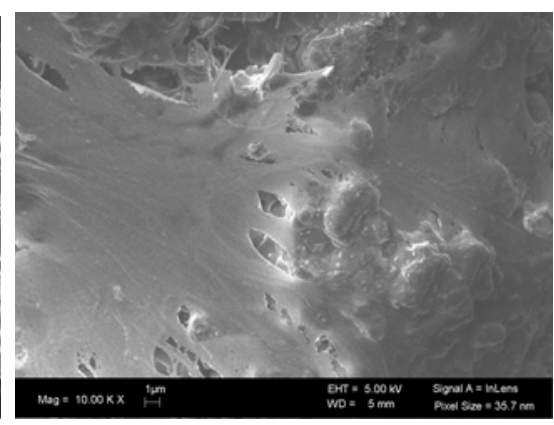

(c)

Superior bone formation has also been demonstrated in ectopic studies of cells seeded onto calcium phosphate scaffolds in comparison with autograft, allograft or cell-seeded allografts [57]. It has been shown in ectopic sites that the ratio of the HA/ $\beta$-TCP in the BCP can influence the rate of MSC induced bone formation, where an optimal balance between the more stable and soluble phases must be achieved in order to promote bone tissue formation [54]. 20/80 HA/ $\beta$-TCP (20 wt \% HA: 80 wt \% $\beta$-TCP) scaffolds seeded with human MSC have been shown to have a higher rate of bone formation over other HA/ $\beta$-TCP ratios, $100 \mathrm{HA}(100 \% \mathrm{HA})$ or $100 \beta$-TCP $(100 \% \beta$-TCP) (Figure 4). More recently, MSC have been cultured for a period of time on BCP in order to promote the formation of a bone-like tissue layer on the implant, prior to its implantation [3]. This technique requires, however, more time for preparation, which can be inconvenient for those patients that need a graft immediately [3]. 
Figure 4. Representative histological micrographs of human MSC loaded onto (a) $100 \mathrm{HA}$, (b) $63 / 37 \mathrm{HA} / \beta$-TCP, (c) $20 / 80 \mathrm{HA} / \beta$-TCP, and (d) $100 \beta$-TCP implanted for 6 weeks in a subcutaneous mouse model [54]. (Reprinted from Arinzeh, T.L.; Tran, T.; Mcalary, J.; Daculsi, G. A comparative study of biphasic calcium phosphate ceramics for human mesenchymal stem-cell-induced bone formation. Biomaterials 2005, 26, 3631-3638, with permission from Elsevier.) Bone was detected throughout the porous structure of 20/80 $\mathrm{HA} / \beta$-TCP and was greater than the other ceramics. (H\&E stain, $10 \times$ objective). Bone is stained pink, ceramic has a shadowy white appearance, loose connective tissue is stained light pink, cells are stained a dark pink.

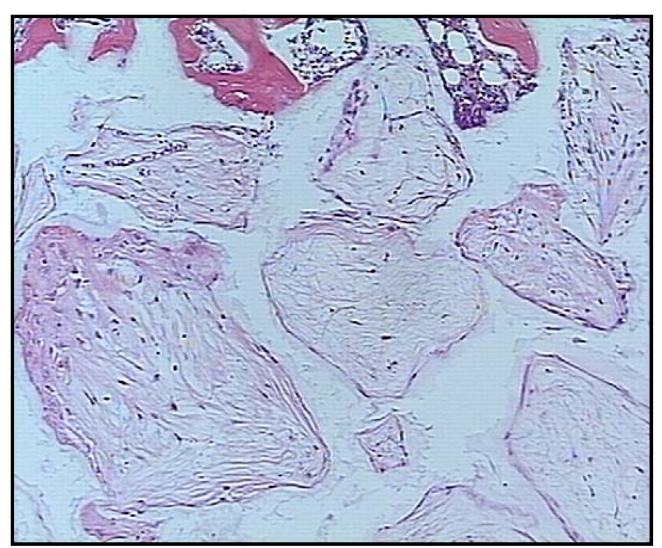

(a)

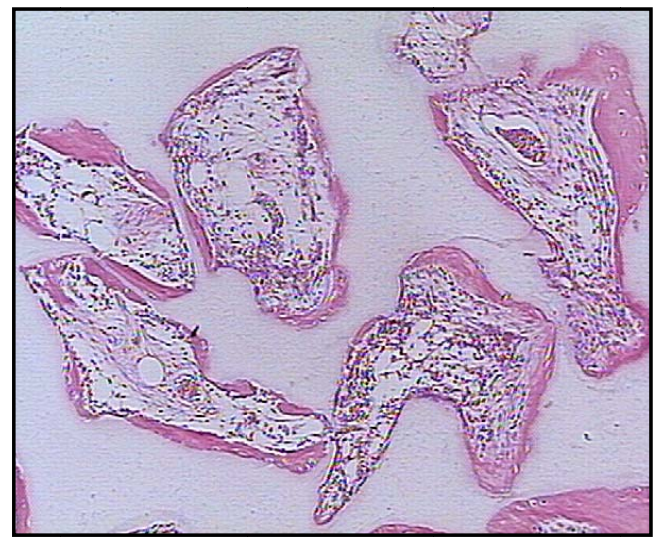

(c)

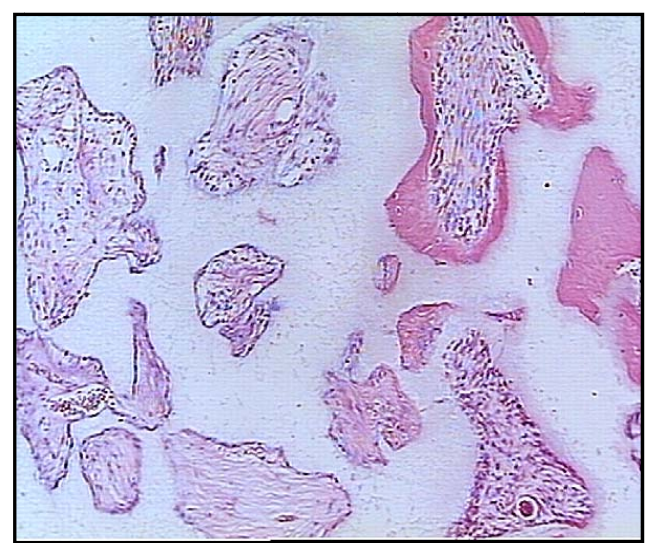

(b)

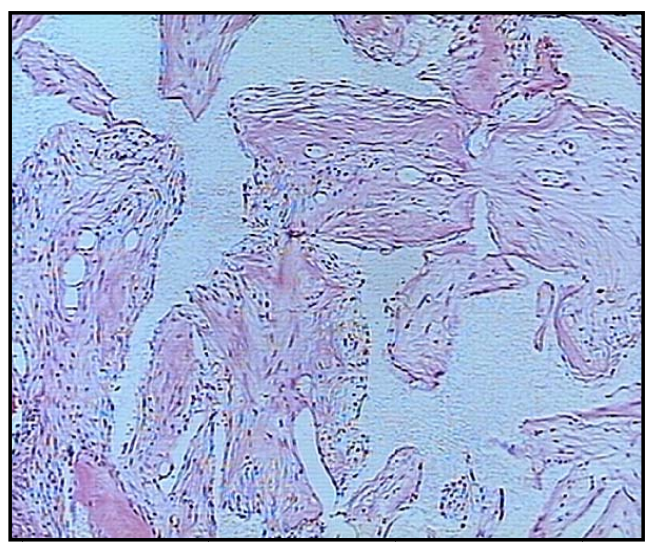

(d)

The successful use of stem cells in repairing bone defects may be related to their osteogenic activity and to the paracrine stimulation of other osteoprogenitors cells and vascular ingrowth [51]. The presence of a biomaterial that is able to mimic the three-dimensional characteristics of the bone tissue, to maintain cell viability, proliferation and differentiation is also critical for the success of such a strategy $[3,4,52]$. Calcium phosphate ceramics are able to maintain the osteogenic capability of stem cells and to induce their differentiation not only in vitro but also in vivo and it is in agreement with the concept of intrinsic osteoinduction [58,59]. However, the relationship between the cell number/dose and the volume of the scaffold used has to be analyzed for each defect $[3,60]$. Moreover, the role of stem cells in the defect environment has yet to be defined. It is not clear if the stem cells are important because they synthesize new bone matrix or because they secrete growth factors which can induce 
bone formation by the host [60]. Consequently, the requirements for the use of a biomaterial, such as a $\mathrm{BCP}$, alone versus in combination with tissue engineering approaches must be defined based on the size and type of the defect.

\section{Conclusions}

$\mathrm{BCP}$ ceramics are shown to be biocompatible, bioactive, osteoconductive, safe, predictable and capable of carrying and inducing the differentiation of stem cells. These characteristics associated with the cost, effectiveness, unlimited supply and absence of disease transmission make them a viable alternative to autografts, allografts and others implants.

The ease of tailoring their chemistry, size and shape make them a versatile matrix for the development of strategies to engineer bone formation. BCP ceramics vary according to their chemical composition and physical structures, which in conjunction with the implantation site, form (granules, blocks and customized pieces) and the intrinsic conditions of the patient, can give rise to different rates and patterns of bone formation. The knowledge of such parameters is essential in choosing a $\mathrm{BCP}$ for a specific application.

\section{References}

1. Gauthier, O.; Bouler, J.M.; Aguado, E.; LeGeros, R.Z.; Pilet, P.; Daculsi, G. Elaboration conditions influence physicochemical properties and in vivo bioactivity of macroporous biphasic calcium phosphate ceramics. J. Mater. Sci. Mater Med. 1999, 10, 199-204.

2. Barrère, F.; van Blitterswijk, C.A.; de Groot, K. Bone regeneration: Molecular and cellular interactions with calcium phosphate ceramics. Int. J. Nanomed. 2006, 1, 317-332.

3. Le Nihouannen, D.; Duval, L.; Lecomte, A.; Julien, M.; Guicheux, J.; Daculsi, G.; Layrolle, P. Interactions of total bone marrow cells with increasing quantities of macroporous calcium phosphate ceramic granules. J. Mater. Sci. Mater. Med. 2007, 18, 1983-1990.

4. Khan, Y.; Yaszemski, M.J.; Mikos, A.G.; Laurencin, C.T. Tissue engineering of bone: Material and matrix considerations. J. Bone Joint. Surg. Am. 2008, 90, 36-42.

5. Schawartz, C.; Liss, P.; Jacquemaire, B.; Lecestre, P.; Frayssinet, P. Biphasic synthetic bone substitute use in orthopaedic and trauma surgery: Clinical, radiological and histological results. $J$. Mater. Sci. Mater. Med. 1999, 10, 821-825.

6. Ransford, A.O.; Morley, T.; Edgar, M.A.; Webb, P.; Passuti, N.; Chopin, D.; Morin, C.; Michel, F.; Garin, C.; Pries, D. Synthetic porous ceramic compared with autograft in scoliosis surgery: A prospective randomized study of 341 patients. J. Bone Join. Surg. Br. 1998, 80, 13-18.

7. Cavagna, R.; Daculsi, G.; Bouler, J. Macroporous calcium phosphate ceramic: A prospective study of 106 cases in lumbar spinal fusion. J. Long Term Eff. Med. Implants 1999, 9, 403-412.

8. Davies, J.E. Bone Engineering; Em Squared Inc: Toronto, Canada, 2000; pp. 516-525.

9. Bagot D`Arc, M.; Daculsi, G. Micro macroporous biphasic ceramics and fibrin sealant as a moldable material for bone reconstruction in chronic otitis media surgery: A 15 years experience. J. Mater. Sci. Mater. Med. 2003, 14, 229-233. 
10. Nich, C.; Bizot, P.; Nizard, R.; Sedel, L. Femoral reconstruction with macroporous biphasic calcium phosphate ceramic in revision hip replacement. Key Engin. Mater. 2003, 240-242, 853-856.

11. Hing, K.A.; Wilson, L.F.; Buckland, T. Comparative performance of three ceramic bone graft substitutes. Spine J. 2007, 7, 475-490.

12. Adamopoulos, O.; Papadopoulos, T. Nanostructured bioceramics for maxillofacial applications. $J$. Mater. Sci. Mater. Med. 2007, 18, 1587-1597.

13. Schindler, O.S.; Cannon, S.R.; Briggs, T.W.; Blunn, G.W. Composite ceramic bone graft substitute in the treatment of locally aggressive benign bone tumors. J. Orthop. Surg. 2008, 16, $66-74$.

14. LeGeros, R.Z.; Lin, S.; Rohanizadeh, R.; Mijares, D.; LeGeros, J.P. Biphasic calcium phosphate bioceramics: Preparation, properties and applications. J. Mater. Sci. Mater. Med. 2003, 14, 201-209.

15. Daculsi, G.; LeGeros, R. Biphasic calcium phosphate (BCP) bioceramics: Chemical, physical and biological properties. Enc. Biomat. Biomed. Eng. 2006, 1-9.

16. Habibovic, P.; Sees, T.M.; van den Doel, M.A.; van Blitterswijk, C.A.; de Groot, K. Osteoinduction by biomaterials-physicochemical and structural influences. J. Biomed. Mater. Res. A 2006, 77, 747-762.

17. Lobo, S.E.; Wykrota, F.H.; Oliveira, A.C.; Kerkis, I.; Mahecha, G.B.; Alves, H.J. Quantification of bone mass gain in response to the application of biphasic bioceramics and platelet concentrate in critical-size bone defects. J. Mater. Sci. Mater. Med. 2009, 20, 1137-1147.

18. Yuan, H.; Kurashima, K.; de Bruijn, J.D.; Li, Y; de Groot, K.; Zhang, X. A preliminary study on osteoinduction of two kinds of calcium phosphate ceramics. Biomaterials 1999, 20, 1799-1806.

19. Daculsi, G.; Layrolle, P. Osteoinductive properties of micro macroporous biphasic calcium phosphate bioceramics. Key Eng. Mat. 2004, 254-256, 1005-1008.

20. Le Nihouannen, D.; Daculsi, G.; Saffarzadeh, A.; Gauthier, O.; Delplace, S.; Pilet, P.; Layrolle, P. Ectopic bone formation by microporous calcium phosphate ceramic particles in sheep muscles. Bone 2005, 36, 1086-1093.

21. Habibovic, P.; Yuan, H.; van der Valk, C.M.; Meijer, G.; van Blitterswijk, C.A.; de Groot, K. 3D microenvironment as essential element for osteoinduction by biomaterials. Biomaterials 2005, 26, 3565-3575.

22. Ripamonti, U.; Crooks, J.; Kirkbride, A.N. Sintered porous hydroxyapaptites with intrinsic osteoinductive activity: Geometric induction of bone formation. S. Afr. J. Sci. 1999, 95, 335-343.

23. Ripamonti, U.; Richter, P.W.; Thomas, M.E. Self-inducing shape memory geometric cues embedded within smart hydroxyapatite-based biomimetic matrices. Plast. Reconstr. Surg. 2007, 120, 1796-1807.

24. Rochet, N.; Loubat, A.; Laugier, J.P.; Hofman, P.; Bouler, J.M.; Daculsi, G.; Carle, G.F.; Rossi, B. Modification of gene expression induced in human osteogenic and osteosarcoma cells by culture on a biphasic calcium phosphate bone substitute. Bone 2003, 32, 602-610.

25. Duan, Y.R.; Zhang, Z.R.; Wang, C.Y.; Chen, J.Y.; Zhang, X.D. Dynamic study of calcium phosphate formation on porous HA/TCP ceramics. J. Mater. Sci. Mater. Med. 2004, 15, $1205-1211$. 
26. Ye, F.; Lu, X.; Lu, B.; Wang, J.; Shi, Y.; Zhang, L.; Chen, J.; Li, Y.; Bu, H. A long-term evaluation of osteoinductive HA/ $\beta$-TCP ceramics in vivo: 4.5 years study in pigs. J. Mater. Sci. Mater. Med. 2007, 18, 2173-2178.

27. Daculsi, G.; LeGeros, R.Z.; Nery, E.; Lynch, K.; Kerebel, B. Transformation of biphasic calcium phosphate ceramics in vivo: Ultrastructural and physicochemical characterization. J. Biomed. Mater. Res. 1989, 23, 883-894.

28. Daculsi, G.; LeGeros, R.Z.; Heughebaert, M.; Barbieux, I. Formation of carbonate-apatite crystals after implantation of calcium phosphate ceramics. Calcif. Tissue Int. 1990, 46, 20-27.

29. de Oliveira, R.S.; Brigado, R.; Madureira, J.F.; Cruz, A.A.; de Mello Filho, F.V.; Alonso, N.; Machado, H.R. Reconstruction of a large complex skull defect in a child: A case report and literature review. Childs Nerv. Syst. 2007, 23, 1097-1102.

30. Hing, K.A. Bioceramic bone graft substitutes: Influence of porosity and chemistry. Int. J. Appl. Ceram. Technol. 2005, 2, 184199.

31. Arcos, D.; Izquierdo-Barba, I.; Vallet-Regí, M. Promising trends of bioceramics in the biomaterials field. J. Mater. Sci. Mater. Med. 2009, 20, 447-455.

32. Zyman, Z.; Glushko, V.; Dedukh, N.; Malyshkina, S.; Ashukina, N. Porous calcium phosphate ceramic granules and their behavior in differently loaded areas of skeleton. J. Mater. Sci. Mater. Med. 2008, 19, 2197-2205.

33. Papadimitropoulos, A.; Mastrogiacomo, M.; Peyrin, F.; Molinari, E.; Komlev, V.S.; Rustichelli, F.; Cancedda, R. Kinetics of in vivo bone deposition by bone marrow stromal cells within a resorbable porous calcium phosphate scaffold: An X-ray computed microtomography study. Biotechnol. Bioeng. 2007, 98, 271-281.

34. Christophy, C.; Rashid, N.; di Silvio, L.; Hing, K.A. Encouraging nature with ceramics: The roles of surface roughness and physio-chemistry on cell response to substituted apatites. Adv. Sci. Tech. 2008, 57, 22-30.

35. Yuan, H.; de Bruijn, J.D.; Li, Y.; Feng, J.; Yang, Z.; de Groot, K.; Zhang, X. Bone formation induced by calcium phosphate ceramics in soft tissue of dogs: A comparative study between porous alpha-TCP and beta-TCP. J. Mater. Sci. Mater. Med 2001, 12, 7-13.

36. Chou, Y.F.; Huang, W.; Dunn, L.C.; Miller, T.A.; Wu, B.M. The effect of biomimetic apatite structure on osteoblast viability, proliferation and gene expression. Biomaterials 2005, 26, 285-295.

37. Berger, C.E.M.; Rathod, H.; Gillespie, J.I.; Horrocks, B.R.; Datta, H.K. Scanning electrochemical microscopy at the surface of bone-resorbing osteoclasts: Evidence for steady-state disposal and intracellular functional compartmentalization of calcium. J. Bone Min. Res. 2001, 16, 2092-2102.

38. Zaidi M.; Moonga B.S.; Huang, C.L. Calcium sensing and cell signaling process in the local regulation os osteoclastic bone resorption. Biol. Rev. Camb. Philos. Soc. 2004, 79, 79-100.

39. Albrektsson, T.; Johansson, C. Osteoinduction, osteoconduction and osseointegration. Eur. Spine J. 2001, 10, S96-S101.

40. Tao, Z.; Toms, B.B.; Goodisman, J.; Asefa, T. Mesoporosity and functional group dependent endocytosis and cytotoxicity of silica nanomaterials. Chem. Res. Toxicol. 2009, 22, 1869-1880.

41. Bhabra, G.; Sood, A.; Fisher, B.; Cartwright, L.; Saunders, M.; Evans, W.H.; Surprenant, A.; Lopez-Castejon, G.; Mann, S.; Davis, S.A.; Hails, L.A.; Ingham, E.; Verkade, P.; Lane, J.; 
Heesom. K.; Newson, R.; Case, C.P. Nanoparticles can cause DNA damage across a cellular barrier. Nat. Nanotechnol. 2009, 4, 876-883.

42. Mahmood M.; Casciano, D.A.; Mocan, T.; Iancu, C.; Xu, Y.; Mocan, L.; Iancu, D.T.; Dervishi, E.; Li, Z.; Abdalmuhsen, M.; Biris, A.R.; Ali, N.; Howard, P.; Biris, A.S. Cytotoxicity and biological effects of functional nanomaterials delivered to various cell lines. J. Appl. Toxicol. 2009, 30, 74-83.

43. Shi, Z.; Huang, X.; Liu, B.; Tao, H.; Cai, Y.; Tang, R. Biological response of osteosarcoma cells to size-controlled nanostructured hydroxyapatite. J. Biomater. Appl. 2009, in press.

44. Fellah, B.H.; Josselin, N.; Chappard, D.; Weiss, P.; Layrolle, P. Inflammatory reaction in rats muscle after implantation of biphasic calcium phosphate micro particles. J. Mater. Sci. Mater. Med. 2007, 18, 287-294.

45. Saldaňa, L.; Sánchez-Salcedo, S.; Izquierdo-Barba, I.; Bensiamar, F.; Munuera, L.; Vallet-Regí, M.; Vilaboa, N. Calcium phosphate-based particles influence osteogenic maturation of human mesenchymal stem cells. Acta. Biomater. 2009, 5, 1294-1305.

46. Logeart-Avramoglou, D.; Anagnostou, F.; Bizios, R.; Petite H. Engineering bone: challenges and obstacles. J. Cell Mol. Med. 2005, 9, 72-84.

47. Graziano, A.; d’Aquino, R.; Cusella-de Angelis, M.G.; de Francesco, F.; Giordano, A.; Laino, G.; Piattelli, A.; Traini, T.; de Rosa, A.; papaccio, G. Scaffold`s surface geometry significantly affects human stem cell bone tissue engineering. J. Cell. Physiol. 2008, 214, 166-172.

48. Hing, K.A.; Annaz, B.; Saeed, S.; Revell, P.A.; Buckland, T. Microporosity enhances bioactivity of synthetic bone graft substitutes. J. Mater. Sci. Mater. Med. 2005, 16, 467-475.

49. Mastrogiacomo, M.; Scaglione, S.; Martinetti, R.; Dolcini, L.; Beltrame, F.; Cancedda, R.; Quarto, R. Role of scaffold internal structure on in vivo bone formation in macroporous calcium phosphate bioceramics. Biomaterials 2006, 27, 3230-3237.

50. Ripamonti, U. Osteoinduction in porous hydroxyapatite implanted in heterotopic sites of different animal models. Biomaterials 1996, 17, 31-35.

51. Giannoni, P.; Mastrogiacomo, M.; Alini, M.; Pearce, S.G.; Corsi, A.; Santolini, F.; Muraglia, A.; Bianco, P.; Cancedda, R. Regeneration of large bone defects in sheep using bone marrow stromal cells. J. Tissue Eng. Regen. Med. 2008, 2, 253-262.

52. Petite, H.; Viateau, V.; Bensaid, W.; Meunier, A.; de Pollak, C.; Bourguignon, M.; Oudina, K.; Sedel, L.; Guillemin, G. Tissue-engineered bone regeneration. Nat. Biotechnol. 2000, 18, 959-963.

53. Yuan, H.; de Bruijn, J.D.; Zhang, X.; van Blitterswijk, C.A.; de Groot, K. Use of an osteoinductive biomaterial as a bone morphogenetic protein carrier. J. Mater. Sci. Mater. Med. 2001, 12, 761-766.

54. Arinzeh, T.L.; Tran, T.; Mcalary, J.; Daculsi, G. A comparative study of biphasic calcium phosphate ceramics for human mesenchymal stem-cell-induced bone formation. Biomaterials 2005, 26, 3631-3638.

55. Marcacci, M.; Kon, E.; Mouhachev, V.; Lavroukov, A.; Kutepov, S.; Quarto, R.; Mastrogiacomo, M.; Cancedda, R. Stem cells associated with macroporous bioceramics for long bone repair: 6- to 7-year outcome of a pilot clinical study. Tissue Eng. 2007, 13, 947-955. 
56. Arinzeh, T.L. Mesenchymal stem cells for bone repair: preclinical studies and potential clinical applications. Foot Ankle Clinics 2005, 10, 651-665.

57. Eniwumide, J.O.; Yuan, H.; Cartmell, S.H.; Meijer, G.J.; de Bruijn, J.D. Ectopic bone formation in bone marrow stem cell seeded calcium phosphate scaffolds as compared to autograft and (cell seeded) allograft. Eur. Cell. Mater. 2007, 14, 30-38; discussion 39.

58. Sun, H.; Ye, F.; Wang, J.; Shi, Y.; Tu, Z.; Bao, J.; Qin, M.; Bu, H.; Li, Y. The upregulation of osteoblast marker genes in mesenchymal stem cells prove the osteoinductivity of hydroxyapatite/tricalcium phosphate biomaterial. Transplant. Proc. 2008, 40, 2645-2648.

59. Matsushima, A.; Kotobuki, N.; Tadokoro, M.; Kawate, K.; Yajima, H.; Takakura, Y.; Ohgushi, H. In vivo osteogenic capability of human mesenchymal cells cultured on hydroxyapatite and on beta-tricalcium phosphate. Artif. Organs. 2009, 33, 474-481.

60. Viateau, V.; Guillemin, G.; Bousson, V.; Oudina. K.; Hannouche, D.; Sedel, L.; LogeartAvramoglou D.; Petite, H. Long-bone critical-size defects treated with tissue-engineered grafts: A study on sheep. J. Orthop. Res. 2007, 25, 741-749.

(C) 2010 by the authors; licensee Molecular Diversity Preservation International, Basel, Switzerland. This article is an open-access article distributed under the terms and conditions of the Creative Commons Attribution license (http://creativecommons.org/licenses/by/3.0/). 